\section{Nena Židov}

Slovenski etnografski muzej

Ljubljana

nena.zidov@etno-muzej.s
DOI $10.32458 /$ ei.26.2

UDK 069:39](497.4):616.2-036.21

Pregledni rad

Primljeno: 25. svibnja 2021.

Prihvaćeno: 8. lipnja 2021.

\title{
Slovenski etnologi, kulturni antropologi in Slovenski etnografski muzej v času covida-19
}

\begin{abstract}
V članku so orisani odzivi slovenskih etnologov in kulturnih antropologov na pandemijo koronavirusa covid-19 tako na področju raziskovanja kot pedagoškega dela na Oddelku za etnologijo in kulturno antropologijo Filozofske fakultete v Ljubljani. Posebna pozornost je posvečena vplivu pandemije na delovanje Slovenskega etnografskega muzeja v Ljubljani.
\end{abstract}

Ključne riječi: Slovenija, pandemija, covid-19, način življenja, raziskovanje, muzeji, Slovenski etnografski muzej

\section{UVOD}

12. marca 2020 je bila v Sloveniji razglašena epidemijo novega koronavirusa, ki je trajala do 15. maja, ko smo kot prva evropska država razglasili konec epidemije. 19. oktobra je bila epidemija ponovno razglašena in še traja. Virus, ki se je doslej v Sloveniji pojavil v treh valovih, je podobno kot drugod po svetu vplival na številna področja življenja tako posameznikov kot celotne družbe. Postal je predmet raziskovanja različnih ved. Pri raziskovanju obnašanja ljudi v času epidemije je pomembna vloga etnologov in antropologov (Muršič 2020: 226). Na epidemijo se je hitro odzvala vsa etnološko-antropološka skupnost v Sloveniji, tako raziskovalci, zaposleni na Znanstvenoraziskovalnem centru Slovenske akademije znanosti in umetnosti (ZRC SAZU), kot predavatelji na Oddelku za etnologijo in kulturno antropologijo Filozofske fakultete Univerze v Ljubljani. Pandemija je močno vplivala na kulturni sektor (za jugovzhodno Evropo gl. Primorac 2021), kamor sodijo tudi muzeji. V Slovenskem etnografskem muzeju (SEM) zaposleni etnologi in kulturni antropologi smo se na pandemijo odzvali 
kot muzealci, nezanemarljiva pa je bila tudi naša osnovna izobrazba, povezana z etnologijo in kulturno antropologijo. V članku bom orisala, kako so se odzvali slovenski etnologi in kulturni antropologi, zaposleni v raziskovalnih in pedagoških ustanovah, bolj podrobno pa bom predstavila vpliv pandemije na delovanje SEM. Članek temelji na že objavljenih člankih, poročilih in virih ter na lastnem sodelovanju in opazovanju.

\section{SLOVENSKI ETNOLOGI IN KULTURNI ANTROPOLOGI V ČASU COVIDA-19}

Slovensko etnološko društvo in Inštitut za slovensko narodopisje ZRC SAZU sta v začetku aprila 2020 vzpostavila participativni spletni dnevnik "Vsakdanjik: Etnološki zapisi", ${ }^{1}$ ki je bil namenjen refleksijam in razpravam o tem, kako (pre)živeti obdobje karantene, ter širšim družbenim temam, povezanim s koronavirusom. Do sredine junija 2020 je bil odziv velik, v rubrikah "O vsakdanjiku", "Premisleki o družbi" in "Utrinki" so objavljali vsaj en prispevek na dan, potem pa je število prispevkov nekoliko upadlo. Do 5. oktobra so zbrali 162 objav, ki so vsebovale tudi fotografije. K nastajanju spletnega dnevnika so se pridružili študentje 2. letnika Oddelka za etnologijo in kulturno antropologijo, ki so v času samoizolacije pisali dnevnike in jih v obliki kratkih esejev objavljali na spletnem dnevniku. Nekaj študentov je v okviru obvezne prakse po spletu zbiralo razno z življenjem v času koronavirusa povezano gradivo. Nekateri so o zbranem gradivu pripravili zapise za "Vsakdanjik". O participativnem dnevniku so poročali tudi mediji (Poljak Istenič in Babič 2020: 82-83), Naško Križnar, raziskovalec Inštituta za slovensko narodopisje ZRC SAZU v pokoju, je v začetku marca člane in članice Slovenskega etnološkega društva povabil k zbiranju fotografij vsakdanjega življenja v času karantene. Zbranih je bilo okoli 600 fotografij (Križnar et al. 2020: 84). Barbara Turk Niskač z Inštituta za slovensko narodopisje ZRC SAZU je s pomočjo spletne ankete aprila 2020 zbirala podatke o vplivu epidemije na vsakdanje življenje otrok in družinsko življenje (2020).

19. maja 2020 je Oddelek za etnologijo in kulturno antropologijo organiziral spletni simpozij "Vsakdanje življenje med epidemijo". Simpozij je bil razdeljen na tematske sklope "Epidemija in zdravstvo", "Družba v epidemiji, epidemija v družbi", "Etnografija med štirimi stenami" in "Mobilnost in mirovanje med pandemijo" (Veselinovič 2020). Znotraj sklopa Etnografija med štirimi stenami sta bila predstavljena tudi dva referata, povezana z delovanjem slovenskih muzejev v času epidemije. Študentje Oddelka za etnologijo in kulturno antropologijo so predstavili izsledke raziskave o delovanju tridesetih muzejev v Sloveniji v obdobju prvega zaprtja. Raziskavo so opravili kot del študijskega procesa, ki je potekal na daljavo. Tedanja direktorica SEM Tanja Roženbergar pa je predstavila delovanje muzeja v času, ko je bil zaprt za obiskovalce (Veselinovič 2020: 108).

Pri vajah predmeta "Etnologija Slovenije 3" so študentke in študenti Oddelka za etnologijo in kulturno antropologijo v študijskem letu 2020/21 raziskovali vplive epidemije

1 https://vsakdanjik.zrc-sazu.si (dostop 15. aprila 2021). 
koronavirusa in z njo povezanih ukrepov na praznovanja in praznike. Zbrano gradivo (fotografije, slikovno gradivo, avdiovizualni zapisi ...) je del Zbirke Koronsko praznično leto Slovencev. ${ }^{2}$ O projektu so 24 . maja 2021 poročali na spletnem dogodku z naslovom "Koronsko praznično leto Slovencev: Zabeležke in vtisi".

Antropolog Dan Podjed, raziskovalec na Inštitutu za slovensko narodopisje ZRC SAZU, je od marca do aprila 2020 na omrežjih Facebook, LinkedIn, Instagram in Twitter objavljal, kašen je vsakdanjik njega in njegove družin v času karantene (Podjed 2020a: 113). Karantenske zapise in komentarje ljudi na njegove zapise je v istem letu strnil v knjigi "Antropologija med štirimi stenami" (Podjed 2020b). Nekateri etnologi in kulturni antropologi so se v zvez s covid-19 in ukrepi, povezanimi z zajezitvijo epidemije pogosto pojavljali in se še pojavljajo v medijih, predvsem Dan Podjed in profesor Rajko Muršič z Oddelka za etnologijo in kulturno antropologijo.

Pandemiji se ni mogel izogniti "Glasnik Slovenskega etnološkega društva”, kjer je bil v 2. številki, objavljeni konec leta 2020, sklop z naslovom "Covid-19”. Prispevki kažejo, kako so se etnologi in kulturni antropologi iz vrst raziskovalcev, profesorjev, muzealcev ... odzvali na izzive in spremembe vsakdanjika kot posledice pandemije (Ličen in Poljak Istenič 2020). Tako objavljeni znanstveni članki v omenjenem "Glasniku" kot tudi v "Etnologu" iz leta 2020 so, če še ne v tematiki, pa v metodologiji dela, že odražali vpliv pandemije. Etnologi in antropologi so morali v času pandemije metodo opazovanja z neposredno udeležbo, povezano z neposrednim stikom z ljudmi, nadomestiti z metodo "oddaljene etnografije", pri čemer so si med drugim pomagali z digitalnimi metodami (gl. Podjed 2021).

V nadaljevanju članka bom podrobneje predstavila odziv Slovenskega etnografskega muzeja v Ljubljani na pandemične razmere.

\section{SLOVENSKI ETNOGRAFSKI MUZEJ V ČASU COVIDA-19}

\section{MUZEJI IN KORONAKRIZA}

11. marca 2020 razglašena pandemija s strani Svetovne zdravstvene organizacije je imela neslutene vplive na delovanje muzejev po vsem svetu. Če so hoteli še naprej opravljati svoje naloge, so se morali zelo hitro odzvati na novo situacijo. Nekatere razmere so bile bolj ali manj skupne vsem muzejem (npr. izguba neposrednega stika z obiskovalci, delo strokovnega osebja od doma v času zaprtja muzejev, doseganje obiskovalcev "na daljavo" ...). Številni muzeji so se soočali z izpadom dohodka od prodanih vstopnic. Med tistimi, ki so bili v največji meri finančno odvisni od lastnih sredstev, se je pojavil strah pred zaprtjem ali potrebo po odprodaji dela zbirk, da bi lahko preživeli. Nekateri so morali odpustiti del zaposlenih, pri čemer so bili najbolj na udaru zunanji muzejski sodelavci. V najugodnejšem položaju so bili vsekakor muzeji, popolnoma ali v večji meri financirani iz javnih sredstev države ali lokalne

2 http://www.etnoinfolab.org/collections?collection_id=31 (dostop 9. maja 2021). 
skupnosti. Tudi po ponovnem odprtju, ko so morali slediti vsem zaščitnim ukrepom, število obiskovalcev ni bilo primerljivo s tistim pred pandemijo.

Muzejem so kaj hitro z analizo stanja in nasveti za delovanje v novih razmerah priskočile na pomoč mednarodne organizacije s področja kulture in posebej muzejev, tako UNESCO (UNESCO 2000; UNESCO 2001), ICOM (International Council of Museums / Mednarodni muzejski svet) (ICOM 2020a; ICOM 2020b) in NEMO (Network of European Museum Organisations / Evropska mreža muzejev) (NEMO 2020; NEMO 2021). Pomagala so tudi nacionalna muzejska združenja. V Sloveniji je Skupnost muzejev Slovenije (SMS) med 7. in 20. aprilom izvedla anketo, pri kateri je sodelovalo 48 muzejev in galerij. Poleg pregleda stanja kot posledice epidemije je SMS pripravila tudi predloge za reševanje njenih posledic. ${ }^{3}$ ICOM Slovenija je leta 2020 muzejem in covidu-19 posvetil decembrsko izdajo revije "ICOM News".

\section{ZBIRANJE VICEV V SEM}

Najbolj odmeven projekt SEM v času pandemije je brez dvoma zbiranje vicev. Vice, povezane s koronavirusom in situacijami, v katerih smo se posledično znašli, smo začeli zbirati 20. marca 2020, pri čemer smo na vice gledali kot na medij in vir za razkrivanje doživljanja vsakdanjika v posebnih življenjskih razmerah. Zaradi prepovedi druženja so se v obdobju prvega zaprtja Slovenije vici prenašali prek elektronskih sporočil, družbenih omrežij, SMS-sporočil ... V muzeju smo za prejemanje vicev odprli poseben elektronski naslov vici.semuzej@gmail.com in oblikovali uredniški odbor, ${ }^{4}$ ki je vice zbiral in delal izbore najboljših, ki jih je objavljal na muzejski spletni strani (Koren Usenik et al. 2020: 11). Pri izboru je imel uredniški odbor kar nekaj težav, saj vsi niso bili primerni za objavo. Vice, ki smo jih prejeli v hrvaščini, srbščini, bosanščini, angleščini ..., smo objavljali v izvirniku in slovenskem prevodu. Večina jih je bila povezana s karanteno, samoizolacijo, odnosi med spoloma, prepovedjo gibanja med občinami, delom od doma, šolanjem na daljavo, nekaj pa je bilo tudi črnega humorja in političnih vicev. Med marcem in septembrom 2020 smo jih prejeli več kot tisoč (Ilaš et al. 2020: 223).

Prva objava izbora petih najboljših vicev je bila 23. marca 2020. Do preklica epidemije v Sloveniji 15. maja smo jih objavljali dnevno, po prvi razglasitvi konca epidemije pa je z vračanjem ljudi v "normalno življenje" število poslanih vicev upadalo, zato smo začeli objavljati tedenske izbore. Število prejetih vicev se je ponovno povečalo septembra z začetkom šolskega leta, ko smo nadaljevali z objavljanjem tedenskih izborov (Ibid.). Eden od ciljev zbiranja in objavljanja vicev je bil tudi razbremeniti ljudi in jim pomagati preživeti obdobje koronakrize, ki je bila še posebno težka v prvem obdobju razglašene epidemije. Da je bil ta cilj dosežen, kaže dejstvo, da smo prejeli veliko pozitivnih odzivov s strani uporabnikov, na muzejski spletni strani pa so bile s

3 http://www.sms-muzeji.si/ckfinder/userfiles/files/Anketa\%20SMS\%20COVID19.pdf (dostop 13. maja 2021).

4 Dokumentalist Miha Špiček, bibliotekar mag. Gregor Ilaš in kustodinji mag. Adela Pukl in mag. Polona ter tedanja direktorica dr. Tanja Roženbergar. 
humorjem povezane strani najbolj obiskane. Projekt zbiranja vicev je bil zelo odmeven tudi v slovenskih medijih. Po objavi Slovenske tiskovne agencije so novico povzeli številni drugi mediji, predstavniki muzeja so o projektu poročali po radiu, televiziji, o projektu so poročali tiskani in spletni mediji (Ibid.: 224).

Projekt je bil odmeven tudi zunaj Slovenije. Poleg nekaterih tujih medijev (npr. RTV Srbija in Al Jazeera Balkans) (Ibid.) je našel svoje mesto tudi v Hiši evropske zgodovine (House of European History) v Bruslju. Muzej, ki se ukvarja z zgodovino evropske celine, je začel v začetku leta 2020 znotraj projekta "Zgodovina v nastajanju: Dokumentiranje covida-19" (History in the making: Documenting Covid) zbirati pričevanja o življenju v Evropi med pandemijo covida-19. ${ }^{5}$ SEM je bil z zbiranjem vicev povabljen tudi k projektu, ki ga vodi Turizem Ljubljana. Pet ljubljanskih kulturnih ustanov je pripravilo spletno razstavo na digitalni platformi KUnstmatrix, na kateri so predstavile svoje načine dokumentiranja koronskega časa (Ibid.: 224-225). Pri zbiranju vicev sodelujemo tudi z Inštitutom za slovensko narodopisje ZRC SAZU.

Na poletno muzejsko noč 20. 6. 2020 (ko v Sloveniji ni bila več razglašena epidemija) smo v SEM kot rezultat zbiranja vicev odprli razstava "Koronski humor: Vici v času epidemije COVID-19" z izborom vicev, zbranih v času med 12. marcem in 31. majem. Avtorja sta bila Miha Špiček in Adela Pukl. Razstava, ki je bila na ogled do 6 . septembra (Ibid.), je predstavljala teme, ki so se v vicih najpogosteje pojavljale: kvas, toaletni papir, šolanje in delo na daljavo, omejitev gibanja med občinami, prazniki in zaščitna oprema (Koren Usenk et al. 2020: 11). V drugem valu epidemije je število poslanih vicev nekoliko zamrlo, zato smo 9. novembra 2020 na muzejski spletni strani obiskovalce ponovno pozvali k pošiljanju. ${ }^{6}$ 7. maja 2021 smo na spletni strani SEM objavili sedemdeseti izbor vicev.

\section{ZBIRANJE ZGODB IZ ČASA COVIDA-19 V SEM}

Ko smo muzej 13. marca 2020 zaradi razglasitve epidemije zaprli, smo razmišljali, kako obiskovalce oz. uporabnike vključiti v muzejske aktivnosti. V povezavi s stalno razstavo "Jaz, mi in drugi: Podobe mojega sveta" je nastal projekt "KDO SEM v času pandemije?" 3. aprila smo obiskovalce muzejske spletne strani povabili k razmisleku, kdo so v času pandemije, koga v tem času najbolj pogrešajo, kaj novega ali drugačnega počnejo v času, ko so prisiljeni ostati doma, kaj novega jim je čas korone prinesel in kaj odnesel, kako se je spremenil njihov pogled na svet in kaj bo po njihovem mnenju po pandemiji drugače. K sodelovanju smo povabili vse starostne skupine (Koren Usenik 2020: 216-217). Na naš poziv se je do jeseni leta 2020 odzvalo devet posameznikov iz različnih koncev Slovenije, ki so nam poslali dva fotografska projekta, zgodbo in pet pesmi. Kot skupina so se odzvali dijaki Gimnazije Vič v Ljubljani, ki so svoje prispevke (misli, pesmi, besedila, zgodbe, meme in fotografije), nastale v okviru pouka angleškega

5 https://historia-europa.ep.eu/sl/zgodovina-v-nastajanju-dokumentiramo-covid-19) (dostop 17. aprila 2021).

6 https://www.etno-muzej.si/sl/novice/povabilo-k-zbiranju-vicev-ali-koronski-humor-jesen-2020 (dostop 12. maja 2021). 
jezika, objavili v elektronskem zborniku z naslovom "Kdo sem v času pandemije" / "Who am I in this time of the pandemic" (Perne 2020). Zbornik in vse druge prispevke smo objavili na muzejski povezavi ${ }^{7}$ (več o projektu gl. Koren Usenik 2020).

\section{SEM KOT KOORDINATOR VARSTVA NESNOVNE KULTURNE DEDIŠČINE}

Na pandemijo se je SEM odzval tudi v vlogi nacionalnega Koordinatorja varstva nesnovne kulturne dediščine. Unesco je 7. maja 2020 odprl spletno platformo o vplivih covida-19 na nesnovno kulturno dediščino ${ }^{8}$ in pozval podpisnice "Konvencije o varovanju nesnovne kulturne dediščine", da poročajo o stanju nesnovne dediščine v svojih državah. SEM kot Koordinator je posredoval nekaj primerov prilagajanja nesnovne kulturne dediščine pandemičnim razmeram v Sloveniji (velikonočni plesi in igre $\mathrm{v}$ Metliki, praznovanje prvega maja, Pot spominov in tovarištva v Ljubljani) ${ }^{9}$ (Židov et al. 2020). Tudi Unescovo 14. letno srečanje strokovnjakov za nesnovno kulturno dediščino Jugovzhodne Evrope, ki je prek spleta potekalo 26. junija 2020, je bilo posvečeno vprašanjem nesnovne kulturne dediščine v času njenega "utišanja" zaradi covida-19. Na srečanju sva predstavnici muzeja sodelovali s predstavitvijo nekaterih epidemiji prilagojenih oblik izvajanja enot nesnovne kulturne dediščine, vpisanih v nacionalni Register nesnovne kulturne dediščine. Predstavnice muzeja še naprej spremljamo vpliv epidemije na enote, vpisane v nacionalni register, razmišljamo pa tudi o izvedbi ankete o vplivu covida-19 na vpisane enote in nosilce.

\section{DigitAlizACIJA IN POVEČANA PRISOTNOST SEM NA SPLETU}

Podobno kot to velja za večino muzejev (ki imajo dostop do interneta) po svetu, v Evropi in Sloveniji, smo tudi v SEM zaradi pandemije in posledično večkratnih zaprtij muzeja dodatno okrepili svojo prisotnost na spletu. Na srečo smo že pred pandemijo digitalizirali kar veliko gradiva, med zaposlenimi pa imamo tudi osebe z znanjem, potrebnim za digitalizacijo in spletno udejstvovanje. Med prvim zaprtjem muzeja (13. marec - 5. maj) smo začeli digitalne vsebine intenzivno dopolnjevati in povečevati svojo prisotnost na spletu. Dejavnejši smo postali tudi na družbenih omrežjih Facebook, Instagram in Twitter. Ob prvem zaprtju, ko je večina zaposlenih delala od doma, smo, da bi kljub vsemu ohranili stik s svojimi obiskovalci in širšo publiko, na muzejski spletni strani odprli novo podstran "SEM od doma", ${ }^{10}$ na kateri smo začeli ponujati raznovrstne vsebine: virtualne sprehode po obstoječih in minulih razstavah, zvoke

7 https://www.etno-muzej.si/sl/novice/kdo-sem-v-casu-pandemije-zbiramo-misli-razmisljanja-verze-zgodbe (dostop 5. maja 2021).

8 https://ich.unesco.org/en/news/unesco-launches-platform-on-living-heritage-and-the-covid-19-pandemic-13263 (dostop 12. marca 2021).

9 https://ich.unesco.org/en/living-heritage-experience-and-covid-19-pandemic-01124?id=00169 (dostop 16. maja 2021).

10 https://www.etno-muzej.si/sl/sem-od-doma (dostop 10. maja 2021). 
z razstav, zbirke predmetov in fotografij, ki jih hrani SEM, filme iz produkcije SEM in digitalno učno uro. Na YouTubu smo že objavljenim vsebinam dodali vodstva po nekaterih preteklih razstavah. ${ }^{11}$ Da bi obiskovalce seznanjali z delom restavratorjev, ki je običajno spregledano, smo na muzejski spletni strani dodali novo rubriko "Med restavratorji". ${ }^{12}$

Dodatno smo poudarili digitalni dostop do muzejske periodične publikacije "Etnolog" in digitalne knjižnice, nekatere naše publikacije pa smo digitalizirali na novo. Na podstrani "SEM z zgodbami"13 smo aprila začeli predstavljati zgodbe muzejskih predmetov in njihove širše kontekste (Poljak Istenič et al. 2020: 94). Od marca do maja 2020 je muzej obiskovalcem na spletni strani ponudil več kot 25.000 digitalnih vsebin in zabeležili smo več kot 100.000 ogledov (Koren Usenik et al. 2020: 10).

Zelo aktivni smo bili na muzejski Facebook strani, kjer smo najavljali muzejske dogodke in poročali o njih. Predstavljali smo zgodbe o muzejskih predmetih. Sledeč letnemu ciklusu smo predstavljali letne praznike, šege in z njimi povezane predmete ter objavljali fotografije in voščilnice iz dokumentacije SEM. V živo smo se javljali z razstav in odprtij razstav, predstavljali predmete in zbirke, imeli predavanja in otrokom brali pravljice. Obiskovalce smo obveščali o novih enotah, vpisanih v Register nesnovne kulturne dediščine in imeli spletne delavnice. V letu 2021 smo na Facebooku začeli vsak prvi dan v mesecu objavljati videe z glavnim junakom Malim mojstrom, ki predstavlja delo različnih obrtnikov in rokodelcev (izdelovanje papirnatih rož, barvanje pirhov, klekljanje).

Zaradi pandemije je bilo moteno delovanje muzeja v mednarodnem projektu "Taking Care". Načrtovane konference smo morali prestaviti na splet, prav tako razgovore z Indijko Kaniko Gupta, aktivistko v rezidenci, ki zaradi pandemije (še) ni mogla priti v Slovenijo. Tudi "5. Seminar etnobotanike" z naslovom "Nabiralništvo - med nagonom in kulturo" je 20. maja 2021 potekal po spletu.

\section{RAZSTAVLJANJE V ČASU EPIDEMIJE}

Zaradi epidemije smo nekatere razstave podaljšali, druge smo prestavili v kasnejši čas ali jih prestavili na splet. Zaradi zaprtja muzeja oziroma omejitve števila obiskovalcev so se spremenila tudi odprtja razstav. Ob ponovnem odprtju muzeja maja 2020 pod sloganom "Spet z vami" smo upoštevali vse zdravstvene predpise, poskrbeli smo tako za varnost obiskovalcev kot zaposlenih. Posebej smo se potrudili za privabljanje publike, ki smo jo v času zaprtja izgubili. Da bi mimoidoče opozorili na ponovno odprtje muzeja, smo na panoje pred vhodom v razstavno hišo zapisovali izbrane vice. 20. februarja smo odprli gostujočo razstavo Etnografskega muzeja Zagreb "Hrvaške otroške igrače med tradicijo in sodobnostjo", ki pa si je obiskovalci v obdobju zaprtja muzeja žal niso

11 https://www.youtube.com/user/etnomuzej/playlists (dostop 6. maja 2021).

12 https://www.etno-muzej.si/med-restavratorji (dostop 8. aprila 2021).

13 https:// etno-muzej.si/sl/sem-z-zgodbami-predmetov (dostop 6. aprila 2021). 
mogli ogledati. Da bi po odprtju nanjo opozorili čim več ljudi in k ogledu privabili tudi otroke, smo pred muzejem na tla narisali igre, ki se jih otroci igrajo na prostem (ristanc in polž). Kljub trudu je bilo število obiskovalcev seveda mnogo nižje kot pred epidemijo. Marca 2020 smo načrtovali obisk kustosa in dveh restavratorjev s Kitajske, ki naj bi nam pomagali pri restavriranju okrasne kitajske stene iz naših zbirk, ki bi jo po restavriranju tudi razstavili, a je bil njihov prihod zaradi pandemije prestavljen. Avgusta 2020 se je SEM pridružil akciji Skupnosti muzejev Slovenije pod naslovom "Naprej v preteklost", ki je z dogodki "v živo", na muzejskih spletnih straneh in socialnih omrežjih skušala spodbuditi k večjemu obisku muzejev in galerij kot varnih prostorov v času korone.

Zaradi drugega vala epidemije v Sloveniji so se muzeji novembra zopet zapirali. Decembra smo razmišljali, kako bi vsaj tistim, ki gredo mimo muzeja, ponudili kanček novoletnega vzdušja. Pod naslovom "V svetlobo oken ujeta dediščina" smo obiskovalce povabili na ogled muzeja od zunaj. V (zvečer osvetljenih) oknih na fasadi razstavne hiše so si mimoidoči lahko ogledali fotografije nekaterih predmetov, razstavljenih v muzeju. Ker Miklavž, Božiček in dedek Mraz niso mogli obiskovati otrok v ustaljenih oblikah, smo lutke s kostumi treh dobrih mož postavili ob zunanje steklene stene muzeja (podobno trgovinskim izložbam) tako, da so bili vidni od zunaj, prav tako tudi repliko Gasparijevih jaslic. Pred vhodom v muzej pa smo na panojih predstavili božično-novoletne voščilnice iz dokumentacije SEM.

Obiskovalcem smo omogočili izložbeni ogled tudi dveh manjših priložnostnih razstav: "Pustni Orači Okič" (februar 2021) in "300 let Škofjeloškega pasijona" (marec-april 2021). Slednjo, ki je bila sicer postavljena na ogled v muzeju, smo po njegovem zaprtju prestavili v “izložbo", po ponovnem odprtju pa zopet na prvotno mesto.

Kljub negotovim razmeram smo od 1. do 31. oktobra z razstavo "Morje - naše življenje: Spomini nabrežinske ribiške družine" gostovali v Trstu. Odprtja razstav so bila v obdobjih zaprtja muzeja virtualna, neposredno smo jih prenašali na Facebooku ali na muzejskem YouTube kanalu. Z razstavo "Kjer so čebele doma" smo zaradi pandemije le virtualno gostovali v Etnografskem muzeju Zagreb. Odprtje je 3. novembra potekalo po YouTube kanalu SEM, spletna razstava pa je bila na ogled na portalu Etnografskega muzeja Zagreb (www.emz.hr) in SEM (www.etno-muzej.si). Tudi odprtje razstave "La Doctora" 20. aprila 2021 je potekalo po YouTube kanalu, v spletni obliki pa so potekali tudi z razstavo povezani spremljevalni dogodki.

Ena od oblik približevanja dediščine ljudem v času epidemije so bile tudi razstave, postavljene na prostem. SEM je avgusta 2020 sodeloval pri panojski razstavi državnih muzejev z naslovom "Naprej v preteklost”, ki je bila na ogled na Muzejski ploščadi pred SEM. Z dvema plakatoma, na katerih je bil izbor fotografij muzejskih predmetov, se je SEM predstavil v okviru projekta "Ulične galerije", na katerem so se v času zaprtja v decembru 2020 na plakatih, postavljenih po mestu, predstavljali ljubljanski muzeji in galerije. Maja 2021 je SEM v okviru Mednarodnega muzejskega dneva sodeloval pri razstavi plakatov na prostem na različnih lokacijah (in objavljenih v virtualni knjižici). S temo "Prihodnost muzejev: Okrevanje in novi izzivi" je želel ICOM opozoriti 
na spremembe, ki jih je prinesla epidemija, in sporočiti, da so v spremembe aktivno vključujejo tudi muzeji, ki lahko s svojim delovanjem prispevajo k pravičnejši in trajnostno naravnani prihodnosti celotne družbe. Na isto temo je bila na mednarodni muzejski dan 18. maja na muzejski ploščadi v organizaciji ICOM Slovenija odprta razstava plakatov nacionalnih muzejev in galerij, pri kateri je sodeloval tudi SEM.

\section{RAZISKOVANJE IN ZBIRANJE MUZEJSKEGA GRADIVA V ČASU EPIDEMIJE}

Korona je vplivala na naše raziskovanje in pridobivanje raznovrstnega gradiva in predmetov na terenu. Tako zaradi omejitev gibanja na občine in regije kot tudi zaradi vzdrževanja medsebojne distance smo bili veliko manj prisotni na terenu. Stike z ljudmi smo vzdrževali s pomočjo telefona ter "klasične" in elektronske pošte. Znašli smo se v situaciji, ko smo jo vsakodnevno živeli, hkrati pa smo razmišljali, kako bomo ta čas kot muzealci ohranili za naše zanamce. V SEM smo se dogovorili, da vsak kustos dokumentira s covidom-19 povezana področja načina življenja in zbira predmetno gradivo, povezano z njegovim kustodiatom. Pri fotografskem dokumentiranju koronskega časa sta bila zelo aktivna tudi dokumentalista. Kot kustodinja za družbeno kulturo sem tako npr. s fotografiranjem dokumentirala zaprtje trgovin in lokalov, izpraznjeno mesto, ograjena otroška igrišča, vrste pred trgovinami, grafite (povezane s koronakrizo in vlado), protivladne proteste, prilagoditve nekaterih šeg (npr. drivein blagoslov velikonočnih jedi) itd. Kar se predmetov tiče, sem zbirala plakate, ki odsevajo koronačas, politične plakate in predmete, povezane s protivladnimi protesti (npr. protestni dežnik), zaščitne maske kot tiste, ki izražajo pripadnost, stališča ... uporabnikov. Nekateri kustosi so lahko v času zaprtja muzeja opravili nekatera dela, za katera prej ni bilo časa.

Čas korone je bil za vse zaposlene v muzeju tudi svojevrstna osebna izkušnja. Večina nas je delala od doma, kar je pogojevalo izgubo neposrednega stika s sodelavci. Sestankovali smo prek Zooma in več komunicirali s pomočjo telefona in e-pošte. Več smo delali na vsebinah, ki smo jih lahko širili po spletu. Tako sem sama na primer pripravila veliko objav za muzejski Facebook. Podobno kot ostali kustosi sem za komuniciranje začela uporabljati aplikaciji Zoom in Teams. S pomočjo aplikacij sem sodelovala na sestankih, strokovnih srečanjih in imela predavanje za študente Oddelka za etnologijo in kulturno antropologijo.

\section{SKLEP}

Koronasituacija za vse muzeje predstavlja velik izziv in je močno zaznamovala njihovo delovanje. V želji, da bi, čeprav "na daleč”, lahko še naprej opravljali svoje naloge, so se nenehno in na različne načine prilagajali novonastalim situacijam. Iskali so načine, kako v spremenjenih oziroma spreminjajočih se razmerah še naprej opravljati svojo družbeno, kulturno in izobraževalno vlogo, hkrati pa so se odzvali tudi z zbiranjem (in nekateri tudi z razstavljanjem) raznovrstnega gradiva, povezanega z življenjem 
v času pandemije. Koronakriza je muzejem ponovno zastavila vprašanja o njihovem poslanstvu, vlogi in odgovornosti, ki jo imajo do družbe. Pandemija se je izkazala kot primeren čas, ko so lahko muzeji preizkušali nove načine delovanja (do katerih so bili prej nekateri tudi skeptični), da so lahko ohranjali dostopnost in opravljali svoje funkcije (Čelik 2020: 15).

Za Slovenski etnografski muzej lahko rečemo, da se je v novih okoliščinah kar dobro znašel. Ker je financiran s strani države, kljub izpadu lastnih prihodkov (prodaja vstopnic, oddaja prostorov) njegovo delovanje ni bilo ogroženo. Relativno hitro se je lahko prilagodil novemu načinu delovanja "na daleč", saj je imel veliko digitaliziranih vsebin že od prej, med kadri pa tudi osebe z znanjem o digitalizaciji in spletnih medijih. Tudi kustosi, večinoma etnologi in kulturni antropologi, z občutkom za opazovanje sprememb v vsakdanjem in prazničnem življenju ljudi, smo se kaj hitro odzvali na nove razmere, tako $\mathrm{v}$ smislu funkcioniranja muzeja $\mathrm{v}$ nenavadnih razmerah kot tudi dokumentiranja "nove realnosti" in zbiranja z njo povezanega predmetnega gradiva. Ocenjujem, da smo kljub novonastalim razmeram ves čas dobro opravljali svoje naloge. Seveda pa je potrebno vzeti v zakup dejstvo, da z delovanjem "na daleč" nismo dosegli obiskovalcev, ki iz različnih razlogov nimajo dostopa do spleta.

\section{LITERATURA I IZVORI:}

ČELIK, Matevž. 2020. “Muzeji in pandemija”. ICOM News Slovenia (december):14-15. http://www.icom-slovenia.si/fileadmin/user_upload/ICOM_2020_web.pdf (dostop 15. januarja 2021).

ICOM, Museums. 2020a. Museums, Museum Professionals and COVID-19: Report. ICOM. https://icom.museum/wp-content/uploads/2020/05/Report-Museums-and-COVID-19. pdf (dostop 12. maja 2021).

ICOM, Museums. 2020b. Museums, Museum Professionals and COVID-19: Follow up Survey: Report. ICOM. https://icom.museum/wp-content/uploads/2020/11/FINAL-EN_Followup-survey.pdf (dostop 12. maja 2021).

ILAŠ, Gregor, PUKL, Adela in Miha ŠPIČEK. 2020. "Zbiranje vicev na temo koronavirusa". Etnolog 30: 222-226.

ILAŠ, Gregor, PUKL, Adela in Miha ŠPIČEK. 2020. "The Slovene Ethnographic Museum and Humour during the Corona". ICME News 91: 20-23.

KOREN USENIK, Anja. 2020. "Kdo sem v času pandemije: Projekt SEM v času koronavirusa”. Etnolog 30: 216-221.

KOREN USENIK, Anja, PUKL, Adela in Miha ŠPIČEK. 2020. "Slovenski etnografski muzej med koronakrizo". ICOM News Slovenia (december): 10-12. http://www.icom-slovenia. si/fileadmin/user_upload/ICOM_2020_web.pdf (dostop 15. januarja 2021.).

KRIŽNAR, Naško et al. 2020. "Podobe iz mehurčka". Glasnik Slovenskega etnološkega društva 60 (2): 84-93.

LIČEN, Daša in Saša POLJAK ISTENIČ. 2020. "Refleksije iz pandemije". Glasnik Slovenskega etnološkega društva 60 (2): 1. 
MURŠIČ, Rajko. 2020. "Pandemic in a Globalised World: Slovenian Perspectives". Inter Faculty 10: 223-233. https://doi.org/10.15068//00162404 (dostop 28. januarja 2021).

NEMO, Survey. 2020. Survey on the Impact of COVID-19 Situation on Museums in Europe: Final Report. https://www.nemo.org/fileadmin/Dateien/public/NEMO_documents/ NEMO_COVID19_Report_12.05.2020.pdf (dostop 15. marca 2021).

NEMO, Follow-up Survey. 2021. Follow-up Survey on the Impact of the COVID-19 Pandemic on Museums in Europe: Final Report. Network of Europian Museum Organisations. https://www. nemo.org/fileadmin/Dateien/public/NEMO_documents/NEMO_COVID19_FollowUpReport_11.1.2021.pdf (dostop 15. marca 2021).

PERNE, Anže ur. 2020. Kdo sem v času pandemije? [Elektronski vir] = Who am I in this time of the pandemic?: Elektronski zbornik izdelkov dijakov in dijakinj. Ljubljana: Gimnazija Vič. http://gimvic.org/dejavnosti/publikacije/kdo_sem_v_casu_pandemije_zbornik.pdf (dostop 10. maja 2021).

PODJED, Dan. 2020a. "Antropologija med štirimi stenami: Od dnevnika na obrežjih do knjige”. Glasnik Slovenskega etnološkega društva 60 (2): 113-114.

PODJED, Dan. 2020b. Antropologija med štirimi stenami: Spoznavanje družbe in sebe med pandemijo. Ljubljana: Založba ZRC.

PODJED, Dan. 2021. "Renewal of Ethnography in the Time of the COVID-19 Crisis". Sociologija i prostor 59 (219): 267-284.

POLJAK ISTENIČ, Saša et al. 2020. "Zaprti za obiskovalce, a še kako aktivni: Muzeji med pandemijo covida-19”. Glasnik Slovenskega etnološkega društva 60 (2): 94-105.

POLJAK ISTENIČ, Saša in Saša BABIČ. 2020. "Vsakdanjik: Participativni spletni dnevnik za zapise iz pandemije in po njej”. Glasnik Slovenskega etnološkega društva 60 (2): 82-83.

PRIMORAC, Jaka. 2021. "Izgubljeni prihodi i pronađena solidarnost: Utjecaj prvog vala pandemije bolesti COVID-19 na kulturni sektor u jugoistočnoj Europi”. Sociologija $i$ prostor 59 (219): 219-237.

TURK NISKAČ, Barbara. 2020. "Vpliv epidemije na vsakdanjik otrok in družinsko življenje: Rezultati ankete aprila 2020”. Glasnik Slovenskega etnološkega društva 60 (2): 110-112.

UNESCO, Museums. 2020. Museums Around the World in the Face of Covid-19: Unesco Report: May 2020. Paris: Unesco. https://unesdoc.unesco.org/ark:/48223/pf0000373530 (dostop 12. maja 2021).

UNESCO, Museums. 2021. Museums Around the World in the Face of Covid-19: Unesco Report: April 2021. Paris: Unesco. https://unesdoc.unesco.org/ark:/48223/pf0000376729_eng (dostop 12. maja 2021).

VESELINOVIČ, Jaro. 2020. "Vsakdanje življenje med epidemijo: Simpozij Oddelka za etnologijo in kulturno antropologijo, Ljubljana in svetovni splet, 19. 5. 2020". Glasnik Slovenskega etnološkega društva 60 (2): 106-109.

ŽIDOV, Nena, JERIN, Anja in Adela PUKL. 2020. "Nesnovna kulturna dediščina v času covida-19”. ICOM News Slovenia (december): 20-21. http://www.icom-slovenia.si/fileadmin/user_upload/ICOM_2020_web.pdf (dostop 15. januarja 2021). 
https://ich.unesco.org/en/news/unesco-launches-platform-on-living-heritage-and-the-covid19-pandemic-13263 (dostop 16. marca 2021).

https:// etno-muzej.si/sl/sem-z-zgodbami-predmetov (dostop 6. aprila 2021).

https://www.etno-muzej.si/med-restavratorji (dostop 8. aprila 2021).

https://vsakdanjik.zrc-sazu.si (dostop 15. aprila 2021).

https://historia-europa.ep.eu/sl/zgodovina-v-nastajanju-dokumentiramo-covid-19) (dostop 17. aprila 2021).

https://www.etno-muzej.si/sl/novice/kdo-sem-v-casu-pandemije-zbiramo-misli-razmisljanja-verze-zgodbe (dostop 5. maja 2021).

http://www.etnoinfolab.org/collections?collection_id=31 (dostop 9. maja 2021).

https://www.etno-muzej.si/sl/sem-od-doma (dostop 10. maja 2021).

https://www.etno-muzej.si/sl/novice/povabilo-k-zbiranju-vicev-ali-koronski-humor-jesen-2020 (dostop 12. maja 2021).

http://www.sms-muzeji.si/ckfinder/userfiles/files/Anketa\%20SMS\%20COVID19.pdf (dostop 13. maja 2021).

https://ich.unesco.org/en/living-heritage-experience-and-covid-19-pandemic-01124?id=00169 (dostop 16. maja 2021). 